\title{
Evaluation of Wheat-Chickpea Intercrops as Influenced by Nitrogen and Weed Management
}

\author{
1,2 Abdulahi, A., ${ }^{1}$ A. Dabbagh Mohammadi Nassab, \\ ${ }^{1}$ S. Nasrolahzadeh, ${ }^{1}$ S. Zehtab Salmasi and ${ }^{2}$ S.S. Pourdad \\ ${ }^{1}$ Department of Plant Eco-Physiology, Faculty of Agriculture, Tabriz University, Tabriz, Iran \\ ${ }^{2}$ Dryland Agricultural Research Institute, P.O.Box 67145-1164, Kermanshah, Iran
}

Received 2012-04-12, Revised 2012-04-14; Accepted 2012-12-04

\begin{abstract}
Wheat and chickpea are most important crops in dryland farming areas of Iran. Weeds have major impact on chickpea grain yield. This experiment was carried out to increase land use efficiency and weed suppression through intercropping in dryland agricultural research station-Sararood, Kermanshah, Iran during 2008-10. The experimental design layout was factorial split plot based on randomized complete block design with three replications. The main plots contained factorial plots of $\mathrm{N}$ fertilization with 3 levels (N1: no fertilization, N2: $60 \mathrm{~kg} \cdot \mathrm{ha}^{-1}$ urea for wheat and $20 \mathrm{~kg} \cdot \mathrm{ha}^{-1}$ for chickpea and N3: Nitragin as a biofertilizer $+30 \mathrm{~kg} \cdot \mathrm{ha}^{-1}$ urea for wheat and chickpea no urea); and weed conditions with 2 levels (weed infested and weed free). The third factor as sub-plots arranged in main plots was cropping patterns with 10 levels (1: wheat Sole Crop (wh.SC), 2: chickpea Sole Crop (ch.SC), 3: wh./ch. Mixed Intercropping (wh./ch.MIC) in 1:1 ratio, 4: wh./ch. MIC in 2:1 ratio, Row Intercropping (RIC) 1row wh.:1 1row ch., 6: Strip Intercropping (SIC) 5wh.1ch.5wh.2ch, 7: SIC 7wh.:2ch., 8: SIC 2wh.:7ch., 9: SIC 9wh.:4ch. and 10: SIC 4wh.:9ch.). Weed and nitrogen factors didn't have significant effect on wheat yield and patterns number 5, 8 and 10 produced highest wheat grain yield respectively. Chickpea yield was significantly reduced by wheat when intercropped, but high Land Equivalent Ratio (LER) derived. Effect of weeds on chickpea Grain Yield (GY) was significant and GY in weed infested was nearly half of GY in weed free condition. LER in weed infested condition in both years was higher than weed free condition. Weed dry matter in five intercropping patterns clearly decreased as compare to chickpea sole crop. It is concluded that intercropping can be used as a method to decrease the inputs of wheat and chickpea crops, especially for nitrogen fertilizing and weed control.
\end{abstract}

Keywords: Actual Yield Loss, Land Equivalent Ratio, Mixed Cropping, Experimental Design, Produced Highest, Intercropping Patterns, Grain Yield (GY)

\section{INTRODUCTION}

Wheat (Triticum aestivum L.) the second important cereal in the world and chickpea (Cicer arietinum L.), the third most important pulse crop play a vital role in global agricultural economy (FAO, 2012). Wheat is produced in the world for both food and feed (Pingali, 1999). The positive effects of pulses in cropping systems are the symbiotic Nitrogen (N2) fixation ability supplying $\mathrm{N}$ for crops, recycling of $\mathrm{N}$-rich crop residues and the break-crop effect in cereal-rich rotations (Jensen, 1997). Soil N availability is known to be heterogeneous distributed in time and space (Stevenson and Kessel, 1997). When growing an intercrop consisting of a grain legume and a cereal at variable soil $\mathrm{N}$ levels, the grain legume has a higher interspecific competitive ability in areas with lower soil $\mathrm{N}$ levels and vice versa for the cereal component. Such self-regulation will result in an

Corresponding Author: Abdulahi, A., Department of Plant Eco-Physiology, Faculty of Agricultural, Tabriz University, Tabriz, Iran Tel: +98 8312333410 Fax: +98 8312333409 
overall better use of $\mathrm{N}$ resources, water, light and other nutrients. Legumes in intercrop are also potential sources of nitrogen nutrient as a complement/supplement to inorganic fertilizers (Banik, 1996).

Non-chemical methods such as cultural weed control are important components of Integrated Weed Management. Effects of crop diversification on weeds have been reviewed by Liebman and Dyck (1993); Liebman and Ohno (1998) and Hatfield et al. (1998). As an example, intercropping leek (Allium porrum L.) with celery (Apium graveolens L.) showed various beneficial effects, such as the reduction of weeds and pests and an improved resource capture, while cropping practices were not hampered (Baumann et al., 2001).

Rotation of dry-farmed wheat-chickpea is the most prevalent rotation in the Kermanshah and also in other western provinces of Iran. Weeds have major impact on chickpea seed yield because of its low competitive ability (Mousavi et al., 2007). Chemical weed control and hand weeding are the methods of weed control in this region, but chemical control due to high cost and environmental problems and hand weeding due to labor cost and time-consuming is not applied by all farmers, so the area under cultivation of chickpea is decreasing.

The objectives of this study were: to evaluate performance of different wheat-chickpea intercropping systems in comparison with mono crops, to compare various nitrogen fertilizer managements regard to crops productivity and weed control and investigating of intercropping efficiency as a cultural weed control measure.

\section{MATERIALS AND METHODS}

\subsection{Experimental Site Description}

The experiment was carried out on the Experimental Farm of the Dryland Agricultural Research Sub-Institute, Kermanshah, Iran (34 $20^{\prime} \mathrm{N}, 47^{\circ} 19^{\prime}$ E) during 2008-9 and 2009-10. Soil properties of experimental site are given in Table 1. Precipitation and temperature data (ombrothermic diagram) during the experimental period and 20 years average are shown in Fig. 1. The experimental site fertilized with recommended doses of phosphorous (30 P2O5 kg.ha ${ }^{-1}$ ) in autumn.

\subsection{Experimental Design, Field Operation and Sampling}

The experimental design layout was factorial split plot based on randomized complete block design with three replications. The main plots contained factorial plots of $\mathrm{N}$ fertilization management with 3 levels (N1: no fertilization, N2: $60 \mathrm{~kg} \cdot \mathrm{ha}^{-1}$ urea $(46 \% \mathrm{~N})$ for wheat and $20 \mathrm{~kg} \cdot \mathrm{ha}^{-1}$ for chickpea and N3: Nitragin as a biofertilizer $+30 \mathrm{~kg} \cdot \mathrm{ha}^{-1}$ urea for wheat and chickpea no urea); and two levels of weed control (WI: no control or weedy and WF: weed free). The third factor as sub plots arranged in main plots was cropping patterns with 10 levels (P1: Wheat Sole crop (wh.SC), P2: chickpea Sole Crop (ch.SC), P3: Mixed Intercropping of wheat-chickpea (wh./ch.MIC) in 1:1 ratio, P4: wh./ch. MIC in 2:1 ratio, P5: Row Intercropping (RIC) 1wh.:1ch., P6: Strip Intercropping (SIC) with 5wh.1ch.5wh.2ch rows, P7: SIC as 7wh.:2ch., P8: SIC as 2wh.:7ch., P9: SIC as 9wh.:4ch. and P10: SIC as 4wh.:9ch. rows) (Fig. 2). The cropping patterns of P1, P6, P9 and P10 cultivated in $17 \mathrm{~cm}$ row spacing and P2, P3, P4, P5, P7 and P8 in $25 \mathrm{~cm}$ row spacing. The intercrop composition was based on the replacement method to ensure that the relative plant density of the intercrop equals the relative density of the sole crop (Wit and Bergh, 1965).

The urea fertilizer applied at one time at sowing time and Nitragin as a biofertilizer (commercial product) solution included mixed of nitrogen fixing bacteria inoculated with seeds. Before sowing, seeds of chickpea in all treatments inoculated with the proper strain of Rhizobium that was prepared from Soil and Water Research Institute of Iran. The subplots had $5 \mathrm{~m}$ length and from 2.0 to $3.25 \mathrm{~m}$ width depend on cropping pattern. In both years on mid November wheat (cv. Azar2) and chickpea (cv. Arman) cultivated in sole and intercropping patterns. Seeding rate was 350 and 35 seed. $\mathrm{m}^{-2}$ for wheat and chickpea, respectively.

For grain yield determination, wheat and chickpea plants were harvested from central rows of each plot. In intercropping treatments, grain yield of both species recorded based on two area as specified or occupied area of each species and total intercropped area. Canopy area index in different intercrops calculated by difference of height of wheat and chickpea at flowering stage. Weeds were identified and data pertaining to weed population and dry matter were recorded after crop flowering stage in wheat, chickpea occupied area (only in second year) and intercropped area (in both years). Dry weight of weeds was determined after oven-drying at $60^{\circ} \mathrm{C}$ temperature for $48 \mathrm{~h}$ to get a constant weight. There were 24 weed species in experimental site that were as follow: (Anthemis cotula L.), (Cephalaria syriaca L. Roemer and Schultes), (Sinapis arvensis L.), (Conringia orientalis L., Dum./Andr.), (Glycyrrhiza glabra L.), (Galium tricornutum Dandy), (Sophora alopecuroides L.), (Bupleurum rotundifolium L.), (Silene conoidea L.), (Adonis aestivalis L.), (Lamium amplexicaule L.). 
Abdulahi, A. et al. / American Journal of Agricultural and Biological Sciences 7 (4) (2012) 447-460

Table 1. Soil properties of experimental site in Sararood station in each yea

\begin{tabular}{|c|c|c|c|c|c|c|c|c|}
\hline & $\begin{array}{l}\text { Absorbable } \\
\text { Phosphorus } \\
\left(\mathrm{mg}^{\circ} \mathrm{kg}^{-1}\right)\end{array}$ & $\begin{array}{l}\text { absorbable } \\
\text { potassium } \\
\left(\mathrm{mg} \cdot \mathrm{kg}^{-1}\right)\end{array}$ & $\begin{array}{l}\text { organic } \\
\text { carbon } \\
(\%)\end{array}$ & $\begin{array}{l}\text { total } \\
\text { nitrogen } \\
(\%)\end{array}$ & Clay $(\%)$ & Silt (\%) & Sand $(\%)$ & $\mathrm{Ph}$ \\
\hline 2008-09 & 9.2 & 9.8 & 0.94 & 0.1 & 35 & 45 & 20 & 7.4 \\
\hline 2009-10 & 9.1 & 9.8 & 0.98 & 0.1 & 38 & 44 & 18 & 7.4 \\
\hline
\end{tabular}

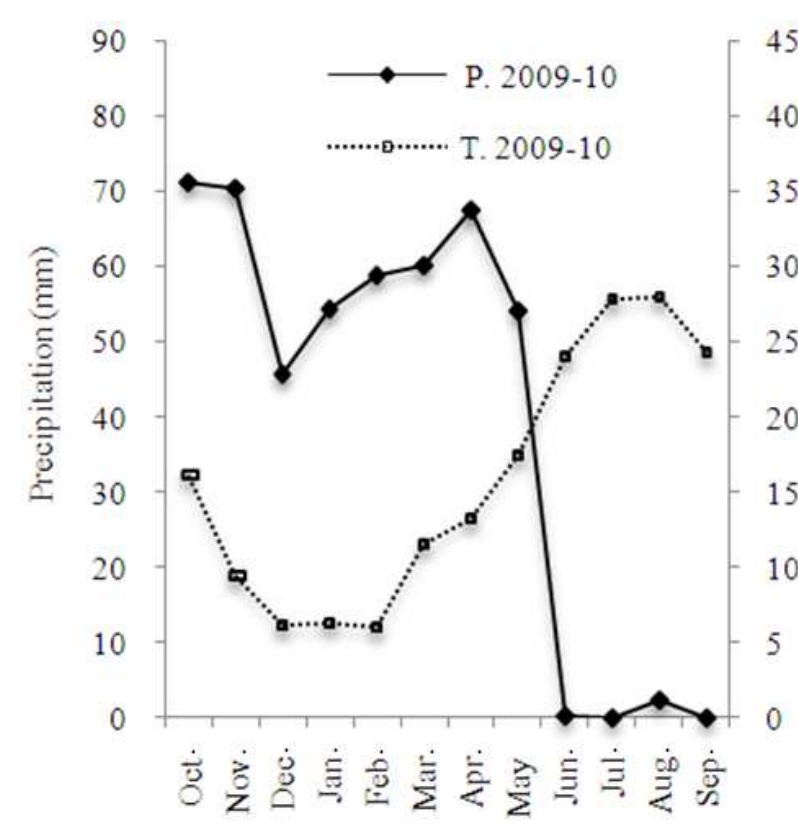

(a)

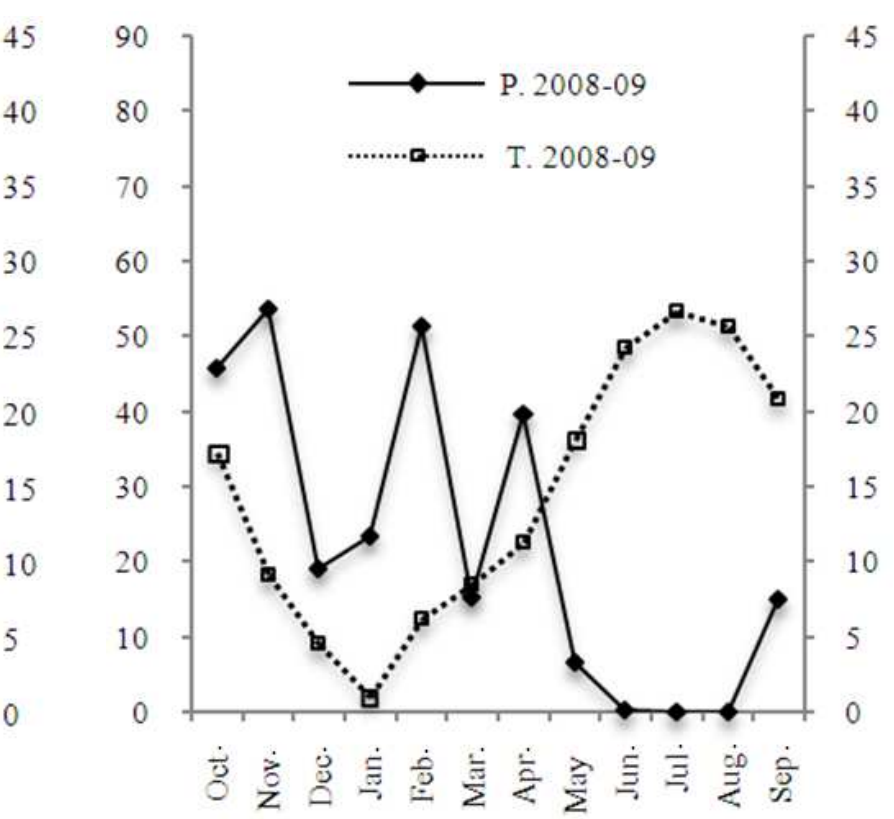

(b)

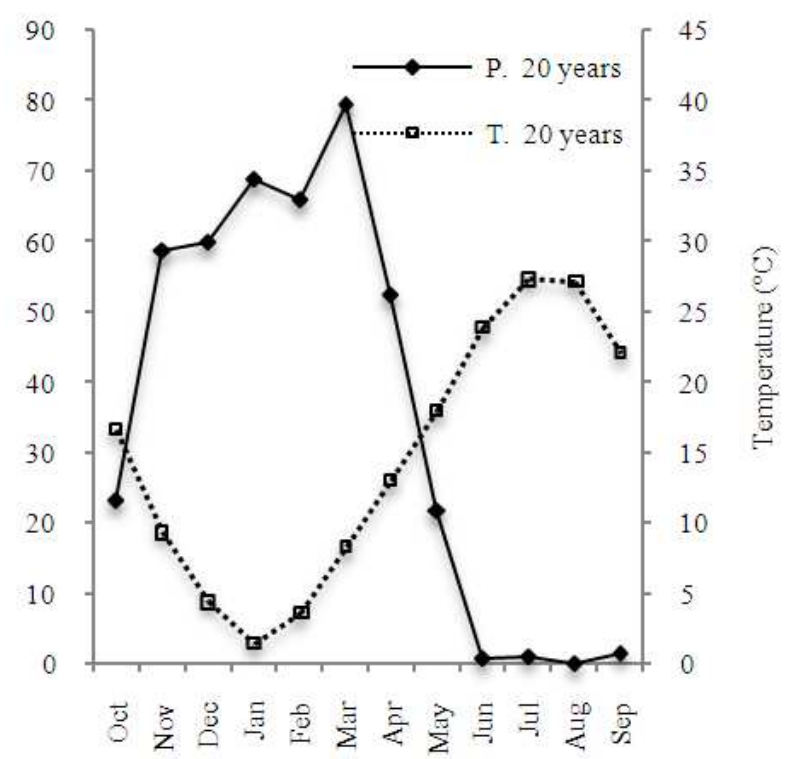

(c)

Fig. 1. Ombrothermic diagram of 2008-9 and 2009-10 in compare to long term (20 years) 


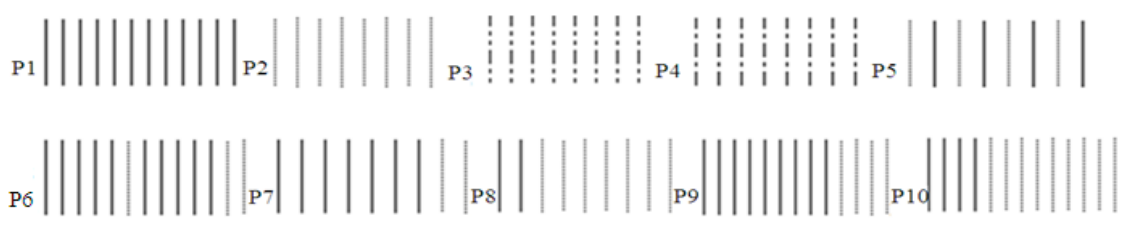

Fig. 2. Cropping patterns used in the experiment. Solid and dashed lines indicate wheat and chickpea row, respectively. P1: wheat sole crop, P2: chickpea sole crop, P3: Mixed Intercropping of wheat-chickpea (wh./ch.MIC) in 1:1 ratio, P4: wh./ch. MIC in 2:1 ratio, P5: Row Intercropping (RIC) 1wh.:1ch., P6: Strip Intercropping (SIC) with 5wh.1ch.5wh.2ch rows, P7: SIC as 7wh.:2ch., P8: SIC as 2wh.:7ch., P9: SIC as 9wh.:4ch. and P10: SIC as 4wh.:9ch. rows

\subsection{Statistical Analysis and Evaluating Indices of Intercrops}

Canopy area index was calculated according to following formula:

Canopy Area Index $=\left(\left(\left(D^{*} \mathrm{Nrc}\right)+(\mathrm{D} * \mathrm{Nrw})+(\mathrm{Ns} *(\mathrm{Hwh}-\right.\right.$ Hch))) / (D* Nrm)

where, D is row spacing; Nrw, number of wheat rows in pattern; Nrc, number of chickpea rows in pattern; Ns, number of wheat row side which are neighbor with chickpea; Hwh, wheat height; Hch, chickpea height; and Nrm is number of total rows (wheat + chickpea) in pattern. The canopy area index value for sole crops (P1 and $\mathrm{P} 2$ ) and mixed intercrops (P3 and p4) is equal to 1 . In mixed intercropping, plants of two species mixed intra-row without separate rows.

The partial actual yields losses, $\mathrm{AYL}_{\text {wheat }}$ or $A Y L_{\text {chickpea, represent the relative decrease of yield per }}$ sowing proportion in intercropping of wheat and chickpea compared to corresponding yields in sole crops (Dhima et al., 2007). The AYL was calculated according to Nassab et al. (2011):

$\mathrm{AYL}_{\text {wheat }}=\left(\left(\mathrm{Y}_{\mathrm{wi}} / \mathrm{Z}_{\mathrm{wi}}\right) /\left(\mathrm{Y}_{\mathrm{w}} / \mathrm{Z}_{\mathrm{w}}\right)\right)-1$ and AYLchickpea $=$ $\left(\left(\mathrm{Y}_{\mathrm{ci}} / \mathrm{Z}_{\mathrm{ci}}\right) /\left(\mathrm{Y}_{\mathrm{c}} / \mathrm{Z}_{\mathrm{c}}\right)\right)-1$

where, $Y_{w}$ and $Y_{w i}$ are the yields of wheat in mono and intercrops, $Y_{c}$ and $Y_{c i}$ are the yields of chickpea in mono and intercrops, respectively. $Z_{\mathrm{wi}}$ and $Z_{\mathrm{ci}}$ are the sown proportions of wheat and chickpea in mixtures, respectively. The partial AYL can have positive or negative values indicating an advantage (dominant component) or disadvantage (dominated component) in intercrops allowing for the comparison of yields on per plant basis.

The advantages of wheat-chickpea intercropping systems were evaluated using the Land Equivalent Ratio (LER) (Willey and Osiru, 1972). LER indicates the efficiency of intercropping for using the environmental resources compared with mono- crops (Mead and Willy, 1980). When LER is $>1$ the intercropping favors growth and yield of species. In contrast, when it is $<1$ there is a disadvantage of intercropping. A LER of 1.0 indicates no advantage of intercropping compared to sole cropping (Nassab et al., 2011). LER was calculated as:

$$
\begin{aligned}
& \mathrm{LER}=\mathrm{LER}_{\text {wheat }}+\mathrm{LER}_{\text {chickpea }} ; \quad \mathrm{LER}_{\text {wheat }}=\mathrm{Y}_{\mathrm{wi}} / \mathrm{Y}_{\mathrm{w}} \\
& \mathrm{LER}_{\text {chickpea }}=\mathrm{Y}_{\mathrm{ci}} / \mathrm{Y}_{\mathrm{c}}
\end{aligned}
$$

where, $Y_{w}$ and $Y_{c}$ are the yields of wheat and chickpea, respectively, as sole crops and $\mathrm{Y}_{\mathrm{wi}}$ and $\mathrm{Y}_{\mathrm{ci}}$ are the yields of wheat and chickpea in intercrops, respectively.

Data of crops grain yield, evaluating indices of intercrops, canopy area index and weed's data were analyzed using the Analysis of Variance (ANOVA) and means compared with LSD (5\%) by IRRISTAT software.

\section{RESULTS}

\subsection{Weeds Density and Dry Matter}

Combined ANOVA of weeds data (density and dry matter) in two years, showed that the main and interaction effects of studied factors (year, nitrogen and cropping patterns) on Weed Density (WD) were no significant, but Weeds Dry Matter (WDM) significantly affected by years, cropping patterns and their interaction and nitrogen levels didn't have significant effect on WDM like WD.

WDM as well as crop yields, in 2008-09 (Y1) were less than 2009-10 (Y2) (Fig. 4), it was because of low rainfall and intense drought stress in Y1 compare to Y2 (Fig. 1). Means comparison of WDM for cropping patterns showed that chickpea SC (P2) had highest WDM and in intercropping patterns (IC, included P3P10) WDM decreased significantly as compare with chickpea SC, but WD in cropping patterns had no significance difference (Fig. 3). 


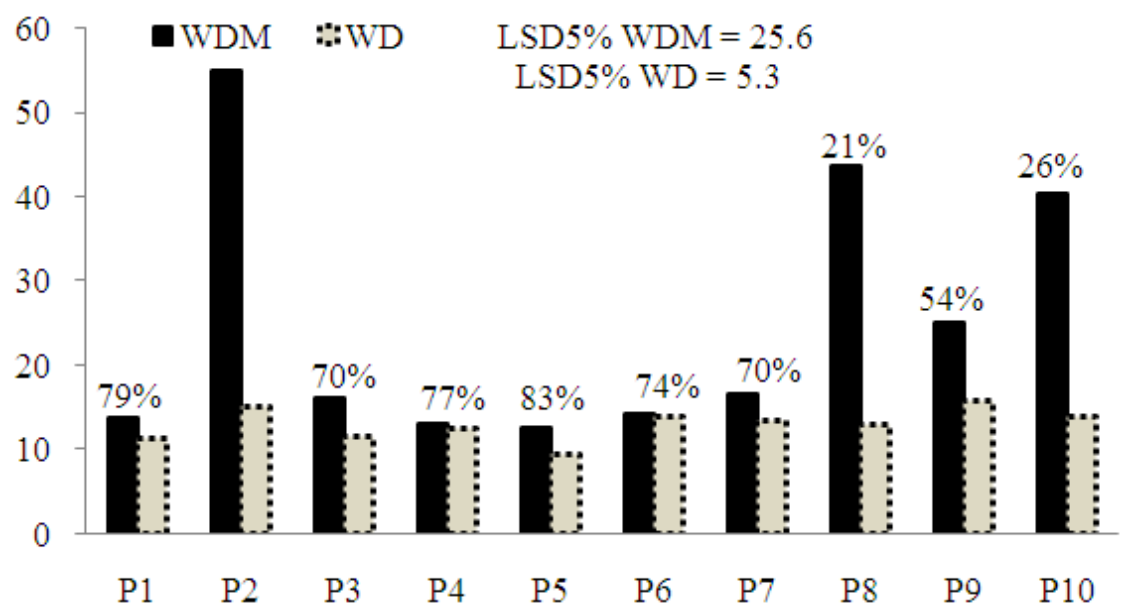

Fig. 3. Weed Dry Matter (WDM, g. $\mathrm{m}^{-2}$ ) and density (WD, plant. $\mathrm{m}^{-2}$ ) for cropping patterns (average two years). Numbers on columns are percentage reduction of WDM related to P2 (chickpea sole crop). P1: wheat sole crop, P2: chickpea sole crop, P3: mixed intercropping of wheat-chickpea (wh./ch.MIC) in 1:1 ratio, P4: wh./ch. MIC in 2:1 ratio, P5: Row Intercropping (RIC) 1wh.:1ch., P6: Strip Intercropping (SIC) with 5wh.1ch.5wh.2ch rows, P7: SIC as 7wh.:2ch., P8: SIC as 2wh.:7ch., P9: SIC as 9wh.:4ch. and P10: SIC as 4wh.:9ch. Rows

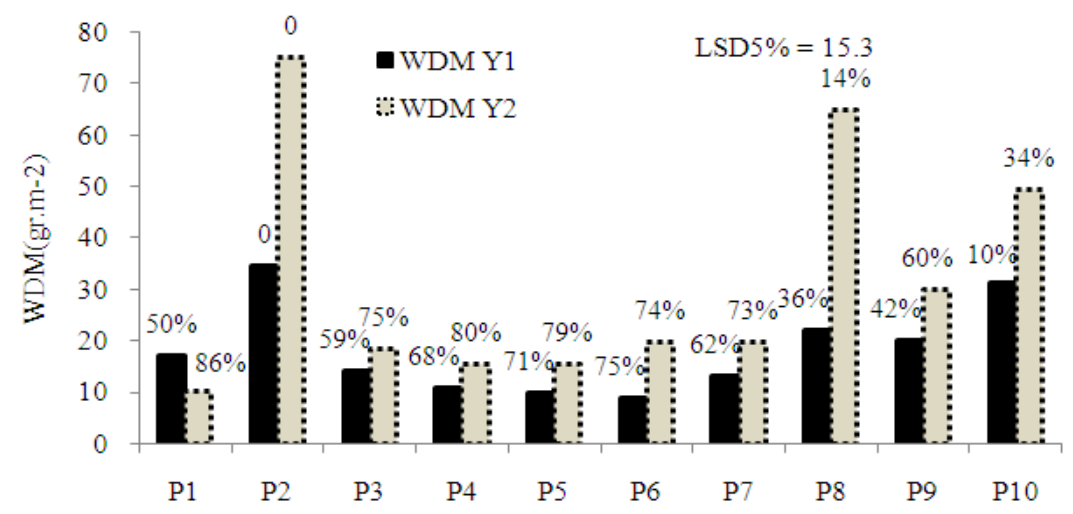

Fig. 4. Weed Dry Matter (WDM, g.m $\mathrm{m}^{-2}$ ) in cropping patterns across years. Numbers on columns are percentage reduction of WDM related to P2 (chickpea sole crop). P1: wheat sole crop, P2: chickpea sole crop, P3: mixed intercropping of wheat-chickpea (wh./ch.MIC) in 1:1 ratio, P4: wh./ch. MIC in 2:1 ratio, P5: Row Intercropping (RIC) 1wh.:1ch., P6: Strip Intercropping (SIC) with 5wh.1ch.5wh.2ch rows, P7: SIC as 7wh.:2ch., P8: SIC as 2wh.:7ch., P9: SIC as 9wh.:4ch. and P10: SIC as 4wh.:9ch. Rows

WDM of patterns differed across years, as in P1 (wh.sc) in second year WDM was less than first year and in other hand in P2 (ch. Sc), P8 and P10 where width of chickpea strip were wide, then WDM in second year was higher than first year, at last in other IC patterns increase in WDM in second year were not considerable like mentioned patterns (Fig. 4). WD and WDM have been determined in IC patterns separately for wheat and chickpea in second year (2009-10). According to analysis of variance WD in chickpea specified area showed no significance differences in nitrogen and cropping patterns, but regard to WDM, only cropping patterns had significant effect and mean comparison of cropping patterns revealed that $\mathrm{P} 2, \mathrm{P} 8$ and $\mathrm{P} 10$ with no significant difference had highest WDM and in five IC patterns (P3, P4, P5, P6, P7) WDM clearly decreased as compare to chickpea sole crop (P2) (Fig. 5a). ANOVA of WD in wheat specified area showed only significant effect of cropping patterns and mean comparison of cropping patterns revealed that P9 and P5 had highest and lowest $\mathrm{WD}$, respectively. Also ANOVA of WDM showed no significance effects of nitrogen and cropping patterns and their interaction on WDM (Fig. 5b). 

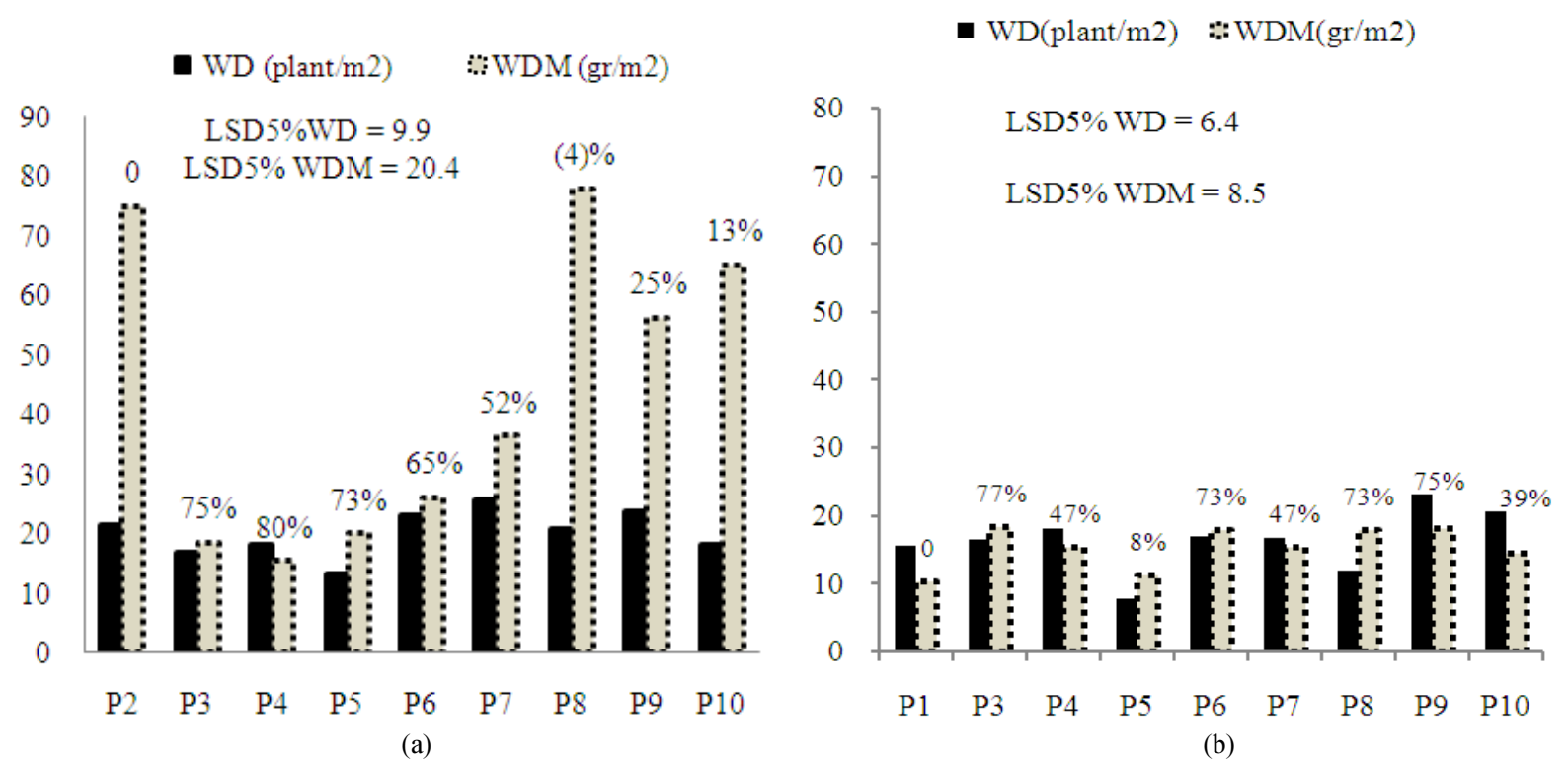

Fig. 5. Weed Density (WD) and Weeds Dry Matter (WDM) in chickpea (a) and wheat (b) specified area in different crop patterns in 2009-10. P1: wheat sole crop, P2: chickpea sole crop, P3: Mixed Intercropping of wheat-chickpea (wh./ch.MIC) in 1:1 ratio, P4: wh./ch. MIC in 2:1 ratio, P5: Row Intercropping (RIC) 1wh.:1ch., P6: Strip Intercropping (SIC) with 5wh.1ch.5wh.2ch rows, P7: SIC as 7wh.:2ch., P8: SIC as 2wh.:7ch., P9: SIC as 9wh.:4ch. and P10: SIC as 4wh.:9ch. rows

Table 2. Canopy Area Index for different IC patterns (P; P5: Row Intercropping of wheat-chickpea (RIC) 1wh.:1ch., P6: Strip Intercropping (SIC) with 5wh.1ch.5wh.2ch rows, P7: SIC as 7wh.:2ch., P8: SIC as 2 wh.:7ch., P9: SIC as 9wh.:4ch. and P10: SIC as 4 wh.:9ch. rows.) across years

\begin{tabular}{llll}
\hline & $2008-09$ & $2009-10$ & Mean \\
\hline P5 & 2.8 & 2.5 & 2.6 \\
P6 & 1.7 & 1.8 & 1.8 \\
P7 & 1.4 & 1.4 & 1.4 \\
P8 & 1.8 & 1.6 & 1.7 \\
P9 & 1.4 & 1.4 & 1.4 \\
P10 & 1.4 & 1.3 & 1.4 \\
mean & 1.7 & 1.7 & \\
LSD5\% & $\mathrm{Y} * \mathrm{P}=0.2$ & $\mathrm{Y}=0.1$ & $\mathrm{P}=0.3$ \\
\hline
\end{tabular}

\subsection{Canopy Area Index}

Light interception is one of the most important traits to photosynthesis and producing assimilates in plants. In Intercropping (IC) systems a raging canopy is created due to height difference between IC components. Canopy area index was analyzed and result of ANOVA indicated that only cropping pattern and it's interaction with year were significant on this index and other factors and interactions were nonsignificant. Row intercropping (P5) had the highest canopy index and P7, P9 and P10 had lowest values (Table 2). Canopy index of different patterns were different across years, as in P2 and P5 in first year were more than second year but in other patterns canopy area index were similar (Table 2).

\subsection{Wheat Grain Yield}

Results of ANOVA showed that effects of year, cropping pattern and their interaction were significant whereas, nitrogen and weed control treatments were no significant on wheat Grain Yield (GY). Wheat GY in 2008-09 was significantly lower than 2009-10, because of intense and long period of drought stress that can be observed in Fig. 1. Comparison of wheat GY among cropping systems indicated that P1 (wh.SC) and P4 (wh./ch. MIC in 2:1 ratio) produced significantly higher GY than other patterns and also wheat GY in P8 was the lowest (Table 3).

Comparison of wheat GY per specified area of that among cropping patterns revealed that intercropping patterns of P5, P8 and P10 produced significantly higher yield as compared to wheat sole crop based on average two years. Intercropping of P3 and other intercrops had lower and same yield with sole crop, respectively (Table 3). Significance of year*pattern interaction showed that the difference of wheat GY in cropping patterns was different across years, whereas wheat GY of SC (P1) in 2009-10 was higher than that in 2008-09 (Table 3). 
Table 3. Wheat grain yield $\left(\mathrm{kg}_{\mathrm{h}} \mathrm{h}^{-1}\right)$ for different cropping patterns (P; P1: wheat sole crop, P3: Mixed Intercropping of wheatchickpea (wh./ch.MIC) in 1:1 ratio, P4: wh./ch. MIC in 2:1 ratio, P5: Row Intercropping (RIC) 1wh.:1ch., P6: Strip Intercropping (SIC) with 5wh.1ch.5wh.2ch rows, P7: SIC as 7wh.:2ch., P8: SIC as 2 wh.:7ch., P9: SIC as 9wh.:4ch. and P10: SIC as 4wh.:9ch. rows) across years (Y) in specified and intercropped area

\begin{tabular}{|c|c|c|c|c|c|c|}
\hline & \multicolumn{3}{|c|}{ Grain yield in intercropped area } & \multicolumn{3}{|c|}{ Grain yield in specified area } \\
\hline & 2008-09 & 2009-10 & Mean & 2008-09 & 2009-10 & Mean \\
\hline P1 & 1824 & 3999 & 2912 & 1824 & 3999 & 2912 \\
\hline P3 & 1701 & 3013 & 2357 & 1701 & 3013 & 2357 \\
\hline P4 & 1730 & 3339 & 2534 & 1730 & 3339 & 2534 \\
\hline P5 & 1371 & 3140 & 2255 & 2742 & 6280 & 4511 \\
\hline P6 & 1609 & 3148 & 2379 & 2092 & 4092 & 3092 \\
\hline P7 & 1510 & 2985 & 2248 & 1942 & 3838 & 2890 \\
\hline P8 & 722 & 1305 & 1013 & 3247 & 5871 & 4559 \\
\hline P9 & 1329 & 2763 & 2046 & 1919 & 3991 & 2955 \\
\hline P10 & 886 & 1621 & 1254 & 2880 & 5269 & 4074 \\
\hline mean & 1409 & 2813 & - & 2231 & 4410 & - \\
\hline LSD5\% & $\mathrm{Y} * \mathrm{P}=232$ & $Y=138$ & $\mathrm{P}=799$ & $\mathrm{Y} * \mathrm{P}=348$ & $Y=198$ & $P=246$ \\
\hline
\end{tabular}

\subsection{Chickpea Grain Yield}

According to ANOVA results, effects of Year (Y), Weed control (W), intercropping Patterns (P) and $\mathrm{Y}^{*} \mathrm{P}$, $\mathrm{W}^{*} \mathrm{P}, \mathrm{Y}^{*} \mathrm{~W}^{*} \mathrm{P}, \mathrm{Y}^{*} \mathrm{~N}$ and $\mathrm{Y}^{*} \mathrm{~W}^{*} \mathrm{~N} * \mathrm{P}$ interactions on chickpea grain yield in both specified and intercropped area were significant. In intercropped area mean comparison of cropping patterns showed that P2 followed by P8, P10 produced highest and P6, P7 and P4 produced lowest chickpea GY (Table 4). Chickpea GY in second year was greater than first year. Chickpea unlike wheat showed high response to weed control; whereas grain yield of that in weedy (WI) treatment was nearly half of that in weed free condition (Table 4).

Significant interaction of $\mathrm{W}^{*} \mathrm{P}$ indicates that arrangement of cropping patterns based on chickpea GY differ in weedy and weed free condition. In weed free condition, GY of sole chickpea and intercropping patterns with high percentage of chickpea (P8 and P10) increased more than other patterns relative to weedy condition (Table 4).

In first Year (Y1), nitrogen treatments had significant difference together, so N3 produced highest chickpea GY, but in second year (Y2) different nitrogen treatments produced same GY (Table 5).

\subsection{Actual Yield Loss (AYL)}

ANOVA results of AYLw indicated that effects of $\mathrm{P}, \mathrm{Y} * \mathrm{P}, \mathrm{W}^{*} \mathrm{~N} * \mathrm{P}$ were significant, but other main and interaction effects were no significant on AYLw. Mean comparison of AYLw in patterns showed P3, P8 and P5 had highest and P6, P7 and P9 had lowest values (Fig. 6). AYLw of patterns were different across years, as in P5, AYLw in first year were less than second year but in the other patterns it was inverse (Fig. 6). ALYw mean comparison of patterns in different conditions of weed and nitrogen showed P3 in N3 and P8 in N1 on weedy condition had highest AYLw and P7 in N2 on both weed free and weedy conditions had lowest AYLw (Table 6). The actual yield loss of wheat $\left(\mathrm{AYL}_{\mathrm{wh}}\right)$ nearly had positive or near to zero values in all intercrops, weed and nitrogen conditions (Table 6), that reveals wheat is dominant crop on chickpea in different studied conditions.

ANOVA results of AYLc indicated that effects of $Y$, $\mathrm{Y}^{*} \mathrm{~W}, \quad \mathrm{Y}^{*} \mathrm{P}, \mathrm{Y}^{*} \mathrm{~W}^{*} \mathrm{P}, \quad \mathrm{Y}^{*} \mathrm{~N}^{*} \mathrm{P}$ and $\mathrm{Y}^{*} \mathrm{~W}^{*} \mathrm{~N}^{*} \mathrm{P}$ were significant, but other main and interaction had no significant effect on AYLc. AYLc in both years was less than zero and in second year was less than first year (Table 7), that can be resulted in favorable climatically condition, wheat is more dominant on chickpea. In weed free condition at both years AYLc were negative but in weedy condition in $\mathrm{Y} 1$ and $\mathrm{Y} 2$ it was negative and positive respectively, so favorable climatically condition in weedy treatment improved competitive ability of chickpea (Table 7). AYLc of all patterns in Y1 at different conditions of weed and nitrogen were negative, but in Y2 only P3 and P4 were negative and other patterns in weedy condition had positive AYLc, so in mixed patterns (P3 and P4) in all conditions wheat was dominant crop. In P8, AYLc at different weed conditions had values near to 0.0 that shows low negative interference from wheat component (Table 7).

ANOVA results of AYL indicated that $\mathrm{W}^{*} \mathrm{~N}$, $\mathrm{Y} * \mathrm{P}, \quad \mathrm{Y}^{*} \mathrm{~W}^{*} \mathrm{P}$ and $\mathrm{Y}^{*} \mathrm{~N}^{*} \mathrm{P}$ interactions were significant, but main effects of $\mathrm{Y}, \mathrm{W}, \mathrm{N}$ and $\mathrm{P}$ were no significant. AYL of WI at N1 and N2 were the highest and AYL of WF at N1 was the lowest (Fig. 7a). 
Abdulahi, A. et al. / American Journal of Agricultural and Biological Sciences 7 (4) (2012) 447-460

Table 4. Chickpea grain yield $\left(\mathrm{kg}_{\mathrm{h}} \mathrm{ha}^{-1}\right)$ in mono and intercropping system (P2: chickpea sole crop, P3: Mixed Intercropping of wheat-chickpea (wh./ch.MIC) in 1:1 ratio, P4: wh./ch. MIC in 2:1 ratio, P5: Row Intercropping (RIC) 1wh.:1ch., P6: Strip Intercropping (SIC) with 5wh.1ch.5wh.2ch rows, P7: SIC as 7wh.:2ch., P8: SIC as 2wh.:7ch., P9: SIC as 9wh.:4ch. and P10: SIC as 4 wh.:9ch. rows), weed condition, years and their interactions, in intercropped and specified (numbers in parentheses) area. In P2, P3 and P4 GY in intercropped and specified area are equal

\begin{tabular}{|c|c|c|c|c|c|c|c|}
\hline & \multicolumn{3}{|l|}{ 2008-09 (Y1) } & \multicolumn{3}{|l|}{ 2008-10(Y2) } & \multirow{2}{*}{$\begin{array}{l}\text { Average } \\
\text { two years } \\
\text { Mean }\end{array}$} \\
\hline & Weedy & Weed free & Mean & Weedy & Weed free & Mean & \\
\hline $\mathrm{P} 2$ & 345.6 & 659.0 & 502.3 & 188.5 & 741.6 & 465.0 & 483.7 \\
\hline P3 & 65.1 & 87.7 & 76.4 & 74.0 & 99.9 & 87.0 & 81.7 \\
\hline P4 & 55.0 & 83.9 & 69.5 & 46.3 & 66.6 & 56.4 & 62.9 \\
\hline P5 & $51.5(103.0)$ & $93.8(187.6)$ & $72.6(145.3)$ & $143.3(286.7)$ & $225.4(450.8)$ & $184.4(368.7)$ & $128.5(257.0)$ \\
\hline P6 & $16.5(71.6)$ & $22.3(96.6)$ & $19.4(84.1)$ & $51.1(221.3)$ & $75.0(325.0)$ & $63.0(273.2)$ & $41.2(178.6)$ \\
\hline P7 & $39.8(179.3)$ & $55.7(250.4)$ & $47.8(214.9)$ & $51.5(231.9)$ & $81.7(367.5)$ & $66.6(299.7)$ & $57.2(257.3)$ \\
\hline P8 & $239.0(307.3)$ & $471.3(605.9)$ & $355.1(456.6)$ & $168.9(217.2)$ & $474.4(609.9)$ & $321.6(413.5)$ & $338.4(435.1)$ \\
\hline P9 & $53.0(172.3)$ & $121.4(394.4)$ & $87.2(283.4)$ & $63.8(207.3)$ & $121.1(393.7)$ & $92.5(300.5)$ & $89.8(291.9)$ \\
\hline P10 & $212.6(307.1)$ & $345.6(449.3)$ & $279.1(403.2)$ & $148.7(214.8)$ & $335.7(484.8)$ & $242.2(349.8)$ & $260.7(376.5)$ \\
\hline Mean & $119.8(178.5)$ & $215.6(318.3)$ & $167.7(248.4)$ & $104.0(187.5)$ & $246.8(393.3)$ & $175.4(290.4)$ & \\
\hline $\begin{array}{l}\text { LSD5\% } \\
\text { in sample }\end{array}$ & $\begin{array}{l}\mathrm{W}^{*} \mathrm{P}=47.9 \\
(54.9)\end{array}$ & $\begin{array}{l}W=28.3 \\
(42.2)\end{array}$ & $\mathrm{P}=33.9(38.8)$ & $\begin{array}{l}\mathrm{W}^{*} \mathrm{P}=48.1 \\
(64.8)\end{array}$ & $\begin{array}{l}W=26.9 \\
(46.0)\end{array}$ & $\begin{array}{l}P=34.0 \\
(45.8)\end{array}$ & \\
\hline ANOVA & & & & & & & \\
\hline LSD5\% & $\mathrm{Y}^{*} \mathrm{P}=33.7$ & & $\mathrm{Y} * \mathrm{~W} * \mathrm{P}=47.7$ & & & & $\mathrm{P}=78.2$ \\
\hline $\begin{array}{l}\text { in combined } \\
\text { ANOVA }\end{array}$ & $(42.2)$ & & $(59.7)$ & & & & $(166.7)$ \\
\hline
\end{tabular}

Table 5. Chickpea grain yield $\left(\mathrm{kg} \mathrm{ha}^{-1}\right)$ in years, nitrogen fertilization treatments (N; N1: no fertilization, N2: $60 \mathrm{~kg} \cdot \mathrm{ha}^{-1} \mathrm{urea}$ for wheat and $20 \mathrm{~kg} \cdot \mathrm{ha}^{-1}$ for chickpea and N3: Nitragin as a biofertilizer $+30 \mathrm{~kg} \cdot \mathrm{ha}^{-1}$ urea for wheat and chickpea no urea) and their interaction

\begin{tabular}{llll}
\hline & $2008-09$ & $2009-10$ & Mean \\
\hline N1 & 143.2 & 175.9 & 159.6 \\
N2 & 163.9 & 162.6 & 163.3 \\
N3 & 195.9 & 187.6 & 191.8 \\
LSD5\% & & $\mathrm{Y} * \mathrm{~N}=34.2$ & $\mathrm{~N}=50.9$ \\
\hline
\end{tabular}

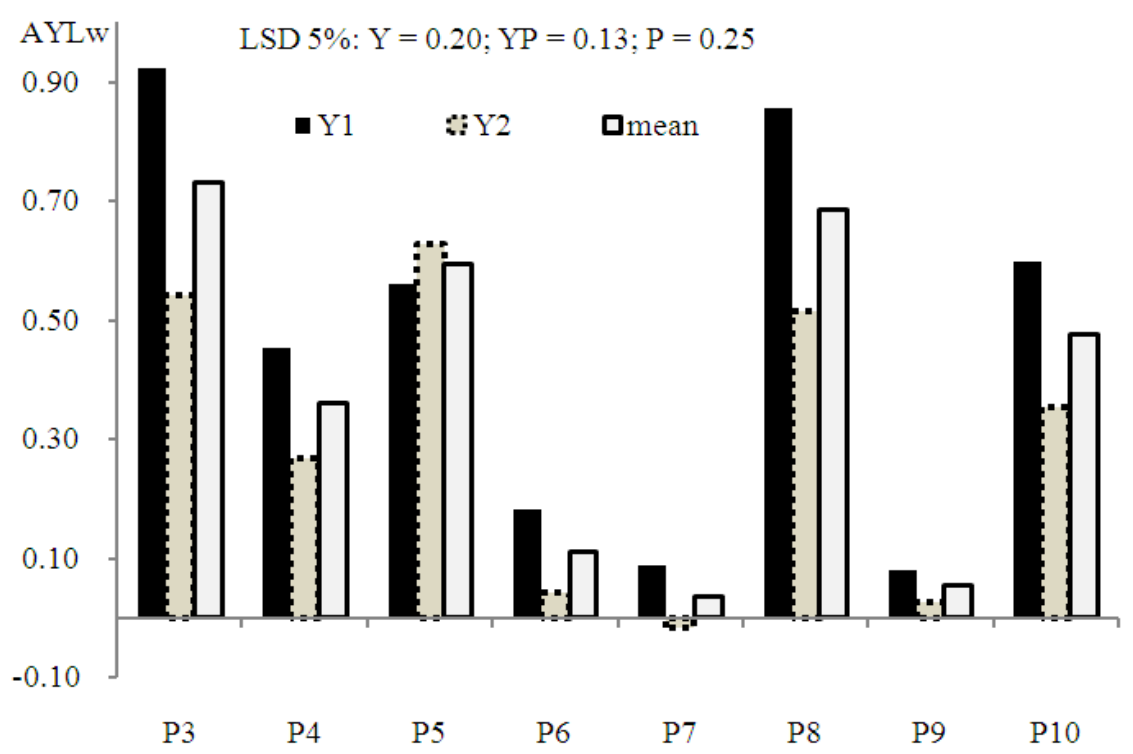

Fig. 6. AYLw in different Patterns across years. P3: Mixed Intercropping of wheat-chickpea (wh./ch.MIC) in 1:1 ratio, P4: wh./ch. MIC in 2:1 ratio, P5: Row Intercropping (RIC) 1wh.:1ch., P6: Strip Intercropping (SIC) with 5wh.1ch.5wh.2ch rows, P7: SIC as 7 wh.:2ch., P8: SIC as 2 wh.:7ch., P9: SIC as 9wh.:4ch. and P10: SIC as 4wh.:9ch. Rows 
Table 6. AYLw in different Patterns (P3: Mixed Intercropping of wheat-chickpea (wh./ch.MIC) in 1:1 ratio, P4: wh./ch. MIC in 2:1 ratio, P5: Row Intercropping (RIC) 1wh.:1ch., P6: Strip Intercropping (SIC) with 5wh.1ch.5wh.2ch rows, P7: SIC as 7wh.:2ch., P8: SIC as 2wh.:7ch., P9: SIC as 9wh.:4ch. and P10: SIC as 4wh.:9ch. Rows) in different weed and N levels (N1: no fertilization, N2: $60 \mathrm{~kg} \cdot \mathrm{ha}^{-1}$ urea for wheat and $20 \mathrm{~kg}^{-h a^{-1}}$ for chickpea and N3: Nitragin as a biofertilizer +30 kg.ha ${ }^{-1}$ urea for wheat and chickpea no urea)

\begin{tabular}{|c|c|c|c|c|c|c|}
\hline & \multicolumn{3}{|c|}{ Weed infested } & \multicolumn{3}{|c|}{ Weed free } \\
\hline & N1 & $\mathrm{N} 2$ & N3 & N1 & N2 & N3 \\
\hline$\overline{\mathrm{P} 3}$ & 0.81 & 0.75 & 0.95 & 0.57 & 0.61 & 0.70 \\
\hline P4 & 0.55 & 0.25 & 0.32 & 0.25 & 0.38 & 0.42 \\
\hline P5 & 0.76 & 0.69 & 0.75 & 0.33 & 0.39 & 0.65 \\
\hline P6 & 0.17 & -0.01 & 0.18 & 0.06 & 0.10 & 0.17 \\
\hline P7 & 0.11 & -0.07 & 0.25 & -0.01 & -0.09 & 0.03 \\
\hline P8 & 0.92 & 0.73 & 0.66 & 0.33 & 0.80 & 0.66 \\
\hline P9 & 0.12 & -0.04 & 0.10 & -0.01 & 0.06 & 0.10 \\
\hline P10 & 0.71 & 0.35 & 0.58 & 0.28 & 0.53 & 0.42 \\
\hline \multicolumn{7}{|c|}{$\mathrm{LSD} 5 \% \mathrm{~W} * \mathrm{~N} * \mathrm{P}=0.17$} \\
\hline
\end{tabular}

Table 7. AYLc of patterns (P3: Mixed Intercropping of wheat-chickpea (wh./ch.MIC) in 1:1 ratio, P4: wh./ch. MIC in 2:1 ratio, P5: Row Intercropping (RIC) 1wh.:1ch., P6: Strip Intercropping (SIC) with 5wh.1ch.5wh.2ch rows, P7: SIC as 7wh.:2ch., P8: SIC as 2wh.:7ch., P9: SIC as 9wh.:4ch. and P10: SIC as 4wh.:9ch. rows) in different weed conditions across years

\begin{tabular}{|c|c|c|c|c|c|c|c|}
\hline & \multicolumn{3}{|l|}{ 2008-09(Y1) } & \multicolumn{4}{|c|}{ 2009-10 (Y2) } \\
\hline & $\begin{array}{l}\text { Weed Infested } \\
\text { (WI) }\end{array}$ & $\begin{array}{l}\text { Weed Free } \\
\text { (WF) }\end{array}$ & $\begin{array}{l}\text { Mean } \\
\text { Y1*P }\end{array}$ & $\begin{array}{l}\text { Weed } \\
\text { infested }\end{array}$ & $\begin{array}{l}\text { Weed } \\
\text { free }\end{array}$ & $\begin{array}{l}\text { Mean } \\
\mathrm{Y} 2 * \mathrm{P}\end{array}$ & $\begin{array}{l}\text { Mean } \\
\text { P }\end{array}$ \\
\hline$\overline{\mathrm{P} 3}$ & -0.58 & -0.73 & -0.65 & -0.15 & -0.71 & -0.43 & -0.56 \\
\hline P4 & -0.43 & -0.61 & -0.52 & -0.16 & -0.71 & -0.44 & -0.49 \\
\hline P5 & -0.68 & -0.71 & -0.69 & 0.63 & -0.39 & 0.12 & -0.37 \\
\hline P6 & -0.77 & -0.85 & -0.81 & 0.30 & -0.55 & -0.13 & -0.54 \\
\hline P7 & -0.44 & -0.61 & -0.52 & 0.35 & -0.49 & -0.07 & -0.34 \\
\hline P8 & -0.08 & -0.08 & -0.08 & 0.24 & -0.19 & 0.02 & -0.04 \\
\hline P9 & -0.46 & -0.39 & -0.42 & 0.16 & -0.47 & -0.16 & -0.32 \\
\hline P10 & -0.10 & -0.22 & -0.16 & 0.24 & -0.34 & -0.05 & -0.12 \\
\hline Mean $\mathrm{Y}^{*} \mathrm{~W}$ & -0.44 & -0.52 & & 0.20 & -0.48 & & \\
\hline Mean & $\mathrm{WI}=0.12$ & $\mathrm{WF}=0.50$ & $Y 1=-0.48$ & Y $2=-0.14$ & & & \\
\hline LSD $5 \%$ & $\mathrm{Y}=0.20$ & $\mathrm{~W}=3.53$ & $\mathrm{YP}=0.1$ & & YWP & & $\mathrm{P}=0.47$ \\
\hline
\end{tabular}

AYL of P3, P4, P8, P9 and P10 were not different across years, but AYL of P5, P6 and P7 were higher in second year (Fig. 7b). Assessment of $\mathrm{Y}^{*} \mathrm{~N}^{*} \mathrm{P}$ treatments for AYL showed considerable fluctuation (according to LSD value) in P5, P6 and P7 but in other patterns it weren't different (Fig. 7c). P5 in Y2WI and P8 in WI at both years had highest and positive AYL and P6 and P7 at Y1WF had lowest and negative AYL (Table 8).

\subsection{Land Equivalent Ratio (LER)}

According to ANOVA results, effects of weed control $(\mathrm{W})$ and $\mathrm{Y}^{*} \mathrm{P}, \mathrm{Y}^{*} \mathrm{~W}^{*} \mathrm{P}$ interactions on LER were significant. Mean comparison of weed treatment showed LER in Weed Infested (WI) condition is higher than Weed Free (WF) condition and revealed superiority of intercropping in this weedy situation $($ LERWI $=1.16$ and LERWF $=0.95)$. Intercropping of P3 and P4 had higher LER values in 2008-09 than 2009-10, then P5 had higher LER value in 2009-10 than 2008-09, also P6, P7 and P9 had LER values equal 1.0 or less than 1.0 in both years and P8 and P10 had stable and LER values greater than 1.0 in both years (Table 9).

LER values difference between P8 in WI with WF in $\mathrm{Y} 1$ is different with that in $\mathrm{Y} 2$ and so in other IC patterns (Fig. 8). 
Abdulahi, A. et al. / American Journal of Agricultural and Biological Sciences 7 (4) (2012) 447-460

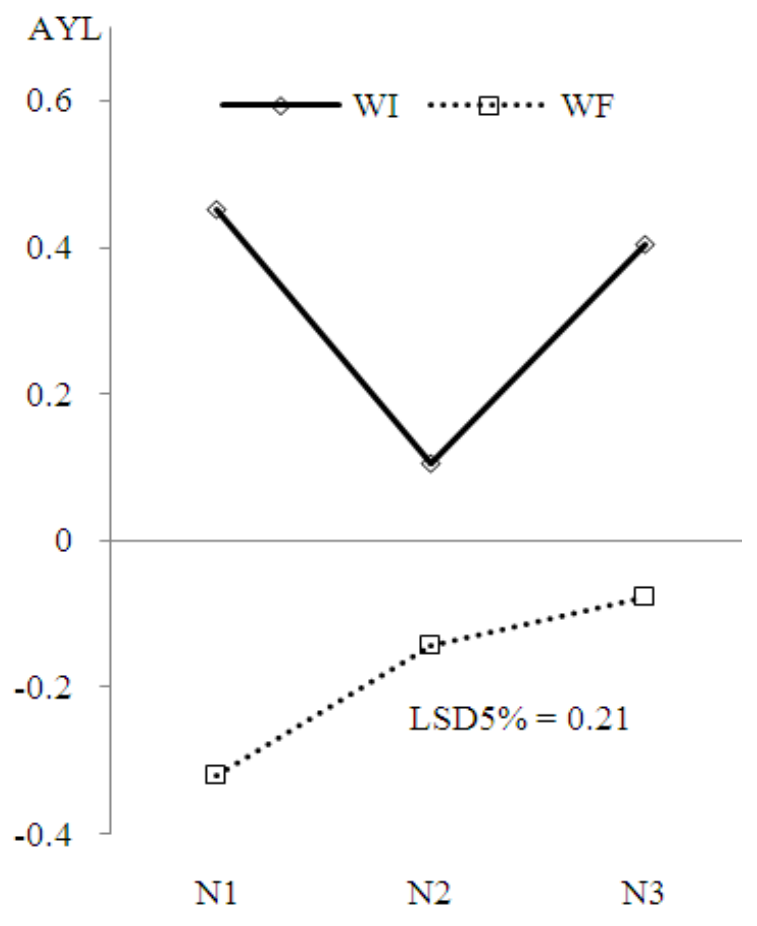

(a)

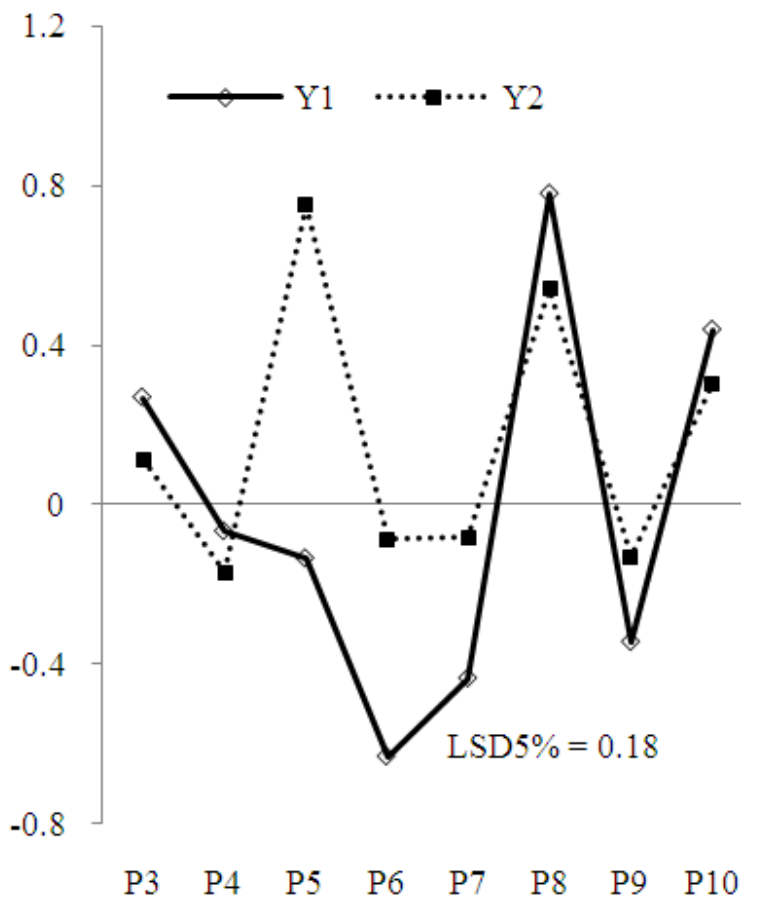

(b)

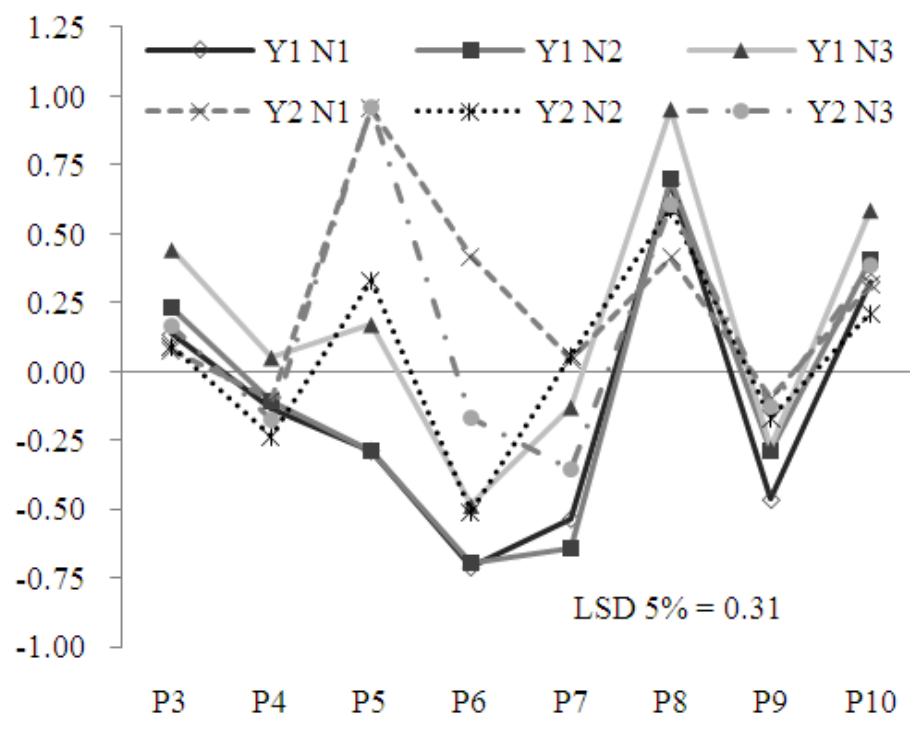

(c)

Fig. 7. AYL in two weed conditions and different N levels (a), AYL of different patterns across years (b), AYL of patterns in different nitrogen levels across years (c). P3: mixed intercropping of wheat-chickpea (wh./ch.MIC) in 1:1 ratio, P4: wh./ch. MIC in 2:1 ratio, P5: Row Intercropping (RIC) 1wh.:1ch., P6: Strip Intercropping (SIC) with 5wh.1ch.5wh.2ch rows, P7: SIC as 7 wh.:2ch., P8: SIC as 2wh.:7ch., P9: SIC as 9wh.:4ch. and P10: SIC as 4wh.:9ch. Rows, N1: no fertilization, N2: 60 kg.ha ${ }^{1}$ urea for wheat and $20 \mathrm{~kg} \cdot \mathrm{ha}^{-1}$ for chickpea and N3: Nitragin as a biofertilizer $+30 \mathrm{~kg} \cdot \mathrm{ha}^{-1}$ urea for wheat and chickpea no urea, WI: weed infested and WF: weed free 


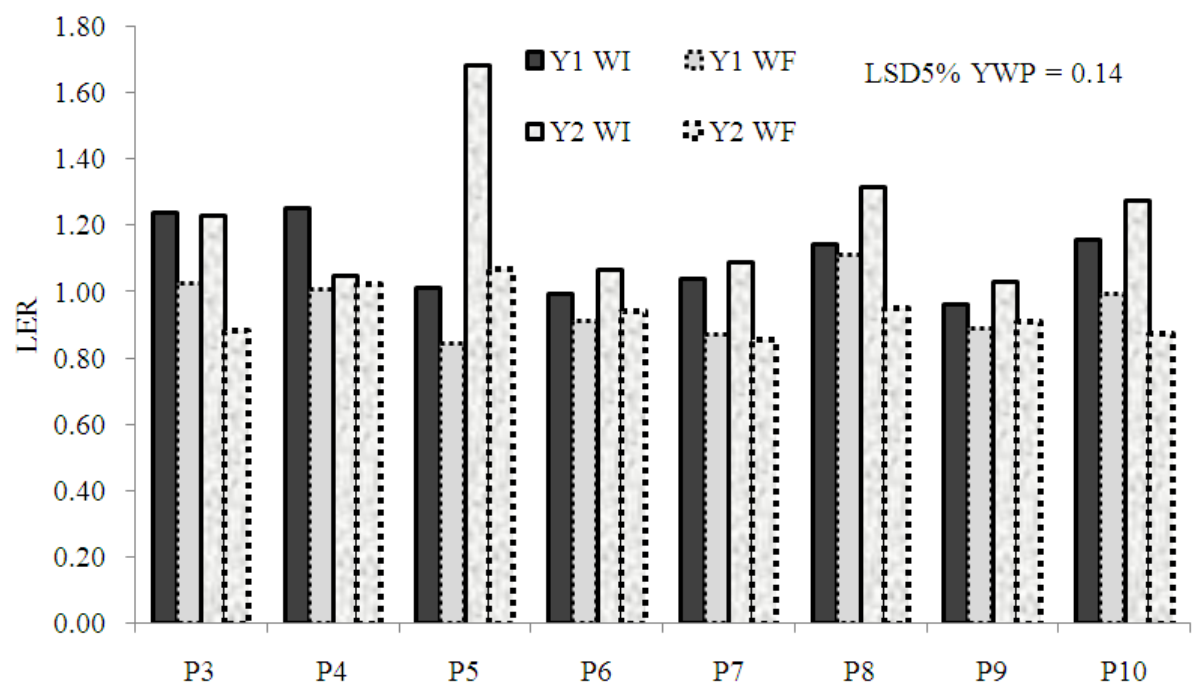

Fig. 8. LER values in different IC patterns at Weed Infested (WI) and Weed Free (WF) conditions in different years. P3: Mixed Intercropping of wheat-chickpea (wh./ch.MIC) in 1:1 ratio, P4: wh./ch. MIC in 2:1 ratio, P5: Row Intercropping (RIC) 1wh.:1ch., P6: Strip Intercropping (SIC) with 5wh.1ch.5wh.2ch rows, P7: SIC as 7wh.:2ch., P8: SIC as 2wh.:7ch., P9: SIC as 9wh.:4ch. and P10: SIC as 4wh.:9ch. Rows

Table 8. AYL of cropping patterns (P3: Mixed Intercropping of wheat-chickpea (wh./ch.MIC) in 1:1 ratio, P4: wh./ch. MIC in 2:1 ratio, P5: Row Intercropping (RIC) 1wh.:1ch., P6: Strip Intercropping (SIC) with 5wh.1ch.5wh.2ch rows, P7: SIC as 7wh.:2ch., P8: SIC as 2wh.:7ch., P9: SIC as 9wh.:4ch and P10: SIC as 4wh.:9ch. rows) in two weed conditions across years

\begin{tabular}{llcrr}
\hline & $2008-09(\mathrm{Y} 1)$ & $2008-9(\mathrm{Y} 2)$ & \\
AYL & Weed Infested (WI) & Weed Free (WF) & Weed Infested(WI) & Weed Free (WF) \\
\hline P3 & 0.49 & 0.05 & 0.46 & 0.23 \\
P4 & 0.16 & -0.29 & -0.01 & -0.33 \\
P5 & 0.04 & -0.31 & 1.37 & 0.13 \\
P6 & -0.55 & -0.71 & 0.29 & -0.47 \\
P7 & -0.27 & -0.60 & 0.37 & -0.54 \\
P8 & 0.86 & 0.70 & 0.84 & 0.24 \\
P9 & -0.31 & -0.37 & 0.13 & -0.39 \\
P10 & 0.63 & 0.24 & 0.60 & 0.01 \\
mean & -0.01 & & 0.15 & YP $=0.18$ \\
LSD5\% & Y=0.26 & YWP $=0.25$ & & \\
\hline
\end{tabular}

Table 9. LER values in different IC patterns (P3: Mixed Intercropping of wheat-chickpea (wh./ch.MIC) in 1:1 ratio, P4: wh./ch. MIC in 2:1 ratio, P5: Row Intercropping (RIC) 1wh.:1ch., P6: Strip Intercropping (SIC) with 5wh.1ch.5wh.2ch rows, P7: SIC as 7wh.:2ch., P8: SIC as 2wh.:7ch., P9: SIC as 9wh.:4ch. and P10: SIC as 4wh.:9ch. rows) in different years. LERwh and LERch are LER for wheat and chickpea, respectively

\begin{tabular}{lllc}
\hline & $\begin{array}{c}2008-09 \\
(\text { LERwh+LERch) }=\text { LER }\end{array}$ & $\begin{array}{l}2009-10 \\
(\text { LERwh+LERch) }=\text { LER }\end{array}$ & Mean \\
\hline P3 & $(0.96+0.17)=1.13$ & $(0.77+0.29)=1.06$ & 1.09 \\
P4 & $(0.98+0.16)=1.13$ & $(0.85+0.19)=1.04$ & 1.08 \\
P5 & $(0.78+0.15)=0.93$ & $(0.82+0.56)=1.38$ & 1.15 \\
P6 & $(0.91+0.04)=0.95$ & $(0.71+0.20)=1.00$ & 0.98 \\
P7 & $(0.85+0.11)=0.95$ & $(0.33+0.21)=0.97$ & 0.96 \\
P8 & $(0.41+0.72)=1.13$ & $(0.71+0.26)=0.97$ & 1.13 \\
P9 & $(0.75+0.18)=0.92$ & $(0.42+0.65)=1.07$ & 0.95 \\
P10 & $(0.50+0.58)=1.07$ & 1.08 & 1.07 \\
Mean & 1.03 & YP $=0.10$ & \\
LSD 5\% & $Y=0.11$ & & $P=0.28$ \\
\hline
\end{tabular}




\section{DISCUSSION}

According to results of this study, reduction in Weed Dry Matter (WDM) has obtained in IC patterns in compare to chickpea SC (Fig. 3-5). The results agreed with findings of Banik et al. (2006) in wheat-chickpea intercrops that reported reduction in weed biomass in intercrops and Baumann et al. (2001) stated celery improved weed suppression in celery-leek intercrop by increasing light interception of canopy. HauggaardNielsen et al. (2003) expressed less weed biomass production and weed density under intercropping system is due to higher inter-specific competition combined with complementarily between intercrop species that improve the crop stand competitive ability towards weeds. Different levels of weed and N didn't have significant influence on wheat GY, but years, patterns and their interaction significantly affected it. GY per intercropping system area indicated that P1 (wh.SC) and P4 produced significantly higher GY than other patterns and produced GY by P8 was the lowest among patterns (Table 3), but wheat GY per specified area in P5, P8 and P10 were located in higher class as compare to wheat SC and other patterns didn't have superiority to SC (Table 3), According to wheat canopy area index mentioned patterns had higher canopy areas compare to other patterns, so likely the reason of yield increase is greater availability of light and higher light use efficiency in these IC patterns. Willey (1979); Vandermeer (1989); Izaurralde et al. (1992) and Waterer et al. (1994) stated light, water and nutrients are often used more efficiently by intercropping than sole crops that is due to differences in competitive ability for growth factors between intercrop components in time and space.

Chickpea was a weak competitor with weeds unlike wheat, consequently weed levels were significantly different and GY in Weed Infested (WI) condition was nearly half of GY in weed free condition (Table 4). GY in $\mathrm{N}$ levels was not significantly different, however N3 had higher GY as compared with other $\mathrm{N}$ levels (Table 5) and N1 had higher GY in second year, that may related to higher rainfall in second year, because the process of $\mathrm{N} 2$ fixation is strongly related to the physiological state of the host plant and it is also highly sensitive to soil water deficiency and in low drought stress activity of rhizobium to fix N2 is better than intense drought stress (Zahran, 1999). Esfahani et al. (2010) in their study on effects of drought stress on N2 fixation in two rhizobium strains of chickpea, reported reduction in N2 fixation in both strains. Grain yield reduction in strip IC patterns which width of chickpea strip was wide (P8), was low and located in highest class (a) with chickpea sole crop, but in other IC patterns whatever width of chickpea strip decreased, grain yield was reduced, This agreed with Jahansooz (1999) that stated the greater separation of the rows of wheat from the rows of chickpea, produced better chickpea yield in the mixture. Mixed patterns of P3 and P4 had lowest and highest yield loss as compared with sole crops that shows high dominance of wheat against chickpea. Greater competitive ability of wheat to exploit resources in association with chickpea has been reported by other researchers (Banik et al., 2006; Li et al., 2002; Jahansooz, 1999).

AYL index gives more precise information about the nature of competition and the behavior of each species in the intercropping system (Banik, 1996). Assessment of AYLw showed wheat is dominant against chickpea in intercropping (Fig. 6 and Table 6). AYLc in WI was higher than AYLc in WF condition (Table 7), that indicates wheat component increased competitive ability of chickpea against weeds that confirms with the reduction of WDM in IC patterns (Fig. 5).

In case of LER, high performance is obtained in plant communities with low competition (Nassab et al., 2011; Willey, 1979). LER values showed advantageous of intercropping in weed infested condition. IC patterns across weed condition showed that intercropping of P5, P3, P8 and P10 in weed infested condition had higher LERs than others, respectively (Table 9). This result is agreed with Weil and McFadden (1991) in maizesoybean intercrops that stated weed stress increased LER. LER responses of IC patterns to different $\mathrm{N}$ levels were no different. Chen et al. (2004) and Weil and McFadden (1991) reported that superiority in IC has obtained in no or low levels of N, but Jahansooz (1999) and Wahla et al. (2009) reported different levels of $\mathrm{N}$ fertilizer didn't affect LER in the intercropping and Nassab et al. (2011) in maize and sunflower intercropping stated applying $\mathrm{N}$ fertilizer improved, decreased or no effect on intercropping performance in different environments (sites*years). Kanayama et al. (1990); Vessey and Waterer (1992) and Parsons et al. (1993) expressed ample supply of inorganic $\mathrm{N}$ will inhibit the N2 fixation in legumes. Higher LER in mixed patterns of P3 and P4 is belonged to first year in wheat component that may be due to lower density of wheat and increase of tolerance of drought stress in these patterns as compare to wheat SC, because in Y1 there was an intense drought stress (Fig. 1), therefore lower density of wheat and its dominance on chickpea provided superiority in LER. Some reasons gather to increase LER 
in P5, P8 and P10 such as high wheat canopy area (Table 2), low competition of wheat with chickpea (AYL results) and reduction in WDM compare to chickpea SC (Fig. 3-5).

\section{CONCLUSION}

Row and strip intercropping of wheat-chickpea with low wheat strip width in low amount of $\mathrm{N}$ fertilizer were advantageous cropping systems and showed superiority on weeds. Finally it is concluded that intercropping can be used as a method to decrease the inputs of wheat and chickpea crops, especially for nitrogen fertilizing and weed control.

\section{ACKNOWLEDGEMENT}

Researchers gratefully acknowledge Tabriz University and Dryland Agricultural Research Institute (DARI) to financial support and facilities for this research.

\section{REFERENCES}

1. Banik, P., 1996. Evaluation of wheat (triticum aestivum) and legume intercropping under 1:1 and 2:1 row-replacement series system. J. Agron. Crop Sci., 176: 289-294. DOI: 10.1111/j.1439-037X.1996.tb00473.x

2. Banik, P., A. Midya, B.K. Sarkar and S.S. Ghose, 2006. Wheat and chickpea intercropping systems in an additive series experiment: Advantages and weed smothering. Eur. J. Agron., 24: 325-332. DOI: 10.1016/j.eja.2005.10.010

3. Baumann, D.T., L. Bastiaans and M.J. Kropff, 2001. Competition and crop performance in a leek-celery intercropping system. Crop Sci., 41: 764-774. DOI: 10.2135/cropsci2001.413764x

4. Chen, C., M., Westcott, K. Neill, D. Wichman and M. Knox, 2004. Row configuration and nitrogen application for barley-pea intercropping in Montana. Agron. J., 96: 17301738. DOI: 10.2134 /agronj2004.1730
5. Dhima, K.V., A.S. Lithourgidis, I.B. Vasilakoglou and C.A. Dordas, 2007. Competition indices of common vetch and cereal intercrops in two seeding ratio. Field Crops Res., 100: 249-256. DOI: 10.1016/j.fcr.2006.07.008

6. Esfahani, M.N., A. Mostajeran and G. Emtiazi, 2010. The effect of drought stress on nitrogenase and antioxidant enzymes activities in nodules formed from symbiosis of chickpea with strains of Mesorhizobium ciceri. World Applied Sci. J., 10: 621-626. http://idosi.org/wasj/wasj 10\%286\%29/2.pdf

7. FAO, 2012. FAO Statistical Yearbook 2012: World Food and Agriculture. 1st Edn., Stylus Pub Llc., ISBN-10: 9251070849, pp: 366.

8. Hatfield, J.L., D.D. Buhler and B.A. Stewart, 1998. Integrated Weed and Soil Management. 1st Edn., Ann Arbor Press, Chelsea, Mich, ISBN-10: 1575040697, pp: 385.

9. Hauggaard-Nielsen, H., P. Ambus and E.S. Jensen, 2003. The comparison of nitrogen use and leaching in sole cropped versus intercropped pea and barley. Nut. Cycl. Agroecosys., 65: 289-300. DOI: 10.1023/A:1022612528161

Start check from here

10. Izaurralde, R.C., W.B. McGill and N.G. Juma, 1992. Nitrogen fixation efficiency, interspecies $\mathrm{N}$ transfer and root growth in barley-field pea intercrop on a Black Chernozemic soil. Biol. Fertil. Soils, 13: 11-16. DOI: 10.1007/BF00337231

11. Jahansooz, M.R., 1999. Wheat-chickpea yield performance, competition and resource use in intercropping, under rainfed conditions of South Australia. Ph.D. Thesis, University of Adelaide. http://digital.library.adelaide.edu.au/dspace/han dle $/ 2440 / 22420$

12. Jensen, E.S., 1997. The Role of Grain Legume N2 Fixation in the Nitrogen Cycling of Temperate Cropping. 1st Edn., Riso National Laboratory, Roskilde, Denmark, pp: 107.

13. Kanayama, Y., I. Watanabe and Y. Yamamoto, 1990. Inhibition of nitrogen fixation in soybean plants supplied with nitrate I. Nitrite accumulation and formation of nitrosylleghemoglobin in nodules. Plant Cell Physiol., 31: 341-346. 
http://pcp.oxfordjournals.org/content/31/3/341.a bstract

14. Li, L., C. Tang, Z. Rengel and F.S. Zhang, 2002. Chickpea facilitates phosphorus uptake by intercropped wheat from an organic phosphorus source. Plant Soil, 248: 297-303. DOI: 10.1023/A:1022389707051

15. Liebman, M. and E. Dyck, 1993. Crop rotation and intercropping strategies for weed management. Ecol. Appli., 3: 92-122. http://www.jstor.org/stable/1941795

16. Liebman, M. and T. Ohno, 1998. Crop Rotation and Legume Residue Effects on Weed Emergence and Growth. In: Integrated Weed and Soil Management, Hatfield, J.L., D.D. Buhler and B.A. Stewart, (Eds.). Ann Arbor Press, ISBN-10: 1575040697, pp: 81221.

17. Mead, R. and R.W. Willey, 1980. The concept of a 'land equivalent ratio' and advantages in yields from intercropping. Exp. Agric., 16: $217-$ 228. DOI: $10.1017 /$ S0014479700010978

18. Mousavi, S.K., P. Pezeshkpour and M. Shahverdi, 2007. Weed population response to chickpea (Cicer arietinum L.) variety and planting date. J. Sci. Technol. Agric. Nat. Resources Summer, 11: 167-176. http://www.sid.ir/en/ViewPaper.asp?ID=97403 $\&$ varStr=14;MOUSAVI\%20S.K.,PEZESHKPO UR\%20P.,SHAHVERDI\%20M.;JOURNAL\%2 0OF\%20SCIENCE\%20AND\%20TECHNOLO GY\%20OF\%20AGRICULTURE\%20AND\%20 NATURAL\%20RESOURCES;SUMMER\%202 $007 ; 11 ; 40 \% 20 \% 28 \mathrm{~A} \% 29 ; 167 ; 176$

19. Nassab, A.D.M., T. Amon and H.P. Kaul, 2011. Competition and yield in intercrops of maize and sunflower for biogas. Indus. Crops Prod., 34: 1203-1211.

DOI: 10.1016/j.indcrop.2011.04.015

20. Parsons, R., A. Stanforth, J.A. Raven and J.I. Sprent, 1993. Nodule growth and activity may be regulated by a feedback mechanism involving phloem nitrogen. Plant Cell Environ., 16: 125-136. DOI: $10.1111 / \mathrm{j} .1365-$ 3040.1993.tb00854.x

21. Pingali, P.L., 1999. CIMMYT 1998-1999 World Wheat Facts and Trends. In: Global Wheat Research in a Changing World: Challenges and Achievements, Pingali, P.L.,
(Ed.)., International Maize and Wheat Improvement Center, Mexico, pp: 1-54.

22. Stevenson, F.C. and C.V. Kessel, 1997. Nitrogen contribution of pea residue in a hummocky terrain. Soil Sci. Soc. Am. J., 61: 494-503.

https://www.soils.org/publications/sssaj/abstract s/61/2/SS0610020494

23. Vandermeer, J.H., 1989. The Ecology of Intercropping. 1st Edn., Cambridge University Press, Cambridge, UK., ISBN-10: 0521345928, pp: 256.

24. Vessey, J.K. and J. Waterer, 1992. In search of the mechanism of nitrate inhibition of nitrogenase activity in legume nodules: Recent developments. Physiol. Plantarum, 84: 171-176. DOI: $10.1111 /$ j.1399-3054.1992.tb08780.x

25. Wahla, I.H., R. Ahmad, Ehsanullah, A. Ahmad and A. Jabbar, 2009. Competitive functions of components crops in some barley based intercropping systems. Int. J. Agric. Biol., 11: 69-72. http://www.fspublishers.org/ijab/pastissues/IJABVOL_11_NO_1/14.pdf

26. Waterer, J.G., J.K. Vessey, E.H. Stobbe and R.J. Soper, 1994. Yield and symbiotic nitrogen fixation in a pea-mustard intercrop as influenced by $\mathrm{N}$ fertilizer addition. Soil Biol. Biol., 26: 447-453. DOI: 10.1016/00380717(94)90176-7

27. Weil, R.R. and M.E. McFadden, 1991. Fertility and weed stress effects on performance of maize/soybean intercrop. Agron. J., 83: 717721.

DOI: 10.2134/agronj1991.00021962008300040014x 
28. Willey, R.W. and D.S.O. Osiru, 1972. Studies on mixtures of maize and beans (Phaseolus vulgaris) with particular reference to plant population. J. Agric. Sci., 79: 517-529. DOI: 10.1017/S0021859600025909

29. Willey, R.W., 1979. Intercropping: Its Importance and Research Needs. Part 1, Competition and Yield Advantages. 1st Edn., Commonwealth Agricultural Bureaux, pp: 20.

30. Wit, C.T.D. and J.P.D. Bergh, 1965. Competition between herbage plants. Neth. J. Agric. Sci., 13: 212-221.

31. Zahran, H.H., 1999. Rhizobium-legume symbiosis and nitrogen fixation under severe conditions and in an arid climate. Microbiol. Mol. Biol. Rev., 63: 968-989.

http://mmbr.asm.org/content/63/4/968.abstract 